\title{
Determinants of Farm Income in Jorhat District of Assam
}

\author{
Dibya Jyoti Kalita* and Ramen Kumar Sarma
}

Department of Agricultural Economics \& Farm Management, College of Agriculture, Assam Agricultural University, Jorhat, India "Corresponding author: dibyajyotikalitajrt@gmail.com (ORCID ID: 0000-0002-5080-052X)

Received: $19-03-2020$

Revised: $22-07-2020$

Accepted: 25-08-2020

\begin{abstract}
The present study was conducted in Jorhat District of Assam to study the factors affecting the farm household income and formulating some policies based on the identified factors. The study was based on sample survey employing multistage random sampling technique and a total number of 120 sample farmers consisting 72 marginal, 22 small, 14 medium and 12 large farmers were selected for generating primary data. A multiple log linear regression analysis was done to work out the factors affecting farmer's income. Out of the seven identified factors, four factors viz., education level of the respondents, size of land holding, social participation \& extension contact and number of income sources were found significant. The relationship of all the variables was found to be positive with the income of the households. Inclusion of agriculture as a subject in the school level; motivation of farmers towards co-operative farming; strengthening the extension contact; dissemination knowledge regarding marketing of the produce, multiple cropping and integrated farming, creation of self help groups amongst the farmers etc. maybe some of policy measures to increase the farm income in the study area.

Highlights

(0 All the seven factors considered were found to have positive impact of farm income.

0 Four factors namely educational level, size of land holding, social participation and number of income sources had significant effect on farm income.
\end{abstract}

Keywords: farm household, farm income, factors affecting farm household income

India is the second populous country in the world after China, with about 1.3 billion people. Agriculture is the backbone of the nation and about 60 percent of the Indian population lives in rural areas practicing agriculture as their main source of livelihood. Nearly half of the workforce of India is involved in agricultural activities. Being the primary occupation for more than 50 percent of the population, agriculture contributes around 17 percent to the Gross Domestic Product of the country. However, the economic condition of this rural population continues to be great concerned and challenge. Despite being the fact that India's food grain production has been increasing every year and tops in terms of production of some crops; such as rice, wheat, pulses, sugarcane; the country's farmers are still far away from realizing the better values of their produce.
It was reported that in most of the developing countries, sufficient survival means of rural households were not seem to be provided by only farming (Bhaumik, 2007). Rural household can earn income from various sources like crop cultivation, livestock rearing, agricultural wage labour and other non farm occupation. With the growing economy and the diversification into various offfarm activities, the rural households also earn a bulk amount of income from the non-farm activities such as working as casual labour, migration to other rural or urban areas and engaging themselves with the salary based activities (T. Ranganathan et al. 2015).

\footnotetext{
How to cite this article: Kalita, D.J. and Sarma, R.K. (2020) Determinants of Farm Income in Jorhat District of Assam. Economic Affairs, 65(3): 357-362.
}

Source of Support: None; Conflict of Interest: None 
There is vast income inequality amongst the farmers of the various regions across the length and breadth of the country. There are different qualitative and quantitative factors responsible for low and varied income of the farmers. But the type and extent of these factors varies with time and location. Different studies have been conducted in different parts of the world as well as India to indentify such factors and measure their effect on farm income. A study performed by Y.K. Sharma et al. (2007) in Rajasthan revealed that family type affected significantly the annual net income of crop farming system and annual gross income of ' crop + vegetable' farming system. It was also found that annual gross income of 'crop + labour' farming system was being affected significantly by the size of land holding, but negatively correlated with the annual net income. Extension contact was found to be significantly and positively related to annual gross income of crop farming system and annual net income of 'crop + vegetable' farming system. Another study done by Mohammad Samaun Safa (2005) disclosed that the income of small scale agro-forestry farmers in Yemen had been influenced significantly by education, area of land holding, livestock holding and family size. M.T. Parvin and M. Akteruzzaman (2013) carried out a research on effects of socio-economic variables on farm and nonfarm income, where they found that farm and nonfarm income were being affected significantly and positively by family size and farm size. However, in Assam quantitative study to measure the effect of different factors on farmers' income is very less. The present study was, therefore, designed to identify and estimate the factors affecting farm household income in Jorhat district of Assam with the following objectives:

1. Identify the factors affecting the farmers' income in the study area, and

2. Examine the effect of each factor on farmers' income

\section{METHODOLOGY}

The study was conducted in the Jorhat district of Assam through sample survey method. Multistage random sampling procedure was followed to draw the sample. In the first stage two ADO circles viz., Titabor and Selenghat from the district were selected at random. In the next stage four villages from each selected ADO circle, namely Kachari gaon, Kharkhua, Borgohain gaon and Chokial from Titabar ADO circle and Phukanbari, Kawoimari, Komargaon and Sumoni sapori from Selenghat ADO circle were randomly selected. A list of all the farm household from the selected villages along with their operational holdings were prepared for categorization of farmers in different groups. The enlisted farm households were categorized in different groups based on their operational holding as follows:

$\begin{array}{ll}\text { Marginal } & <1 \text { ha } \\ \text { Small } & \text { above } 1 \text { ha to } 2 \text { ha } \\ \text { Medium } & \text { above } 2 \text { ha to } 4 \text { ha } \\ \text { Large } & >4 \text { ha }\end{array}$

To draw the final sample, 10 percent of farm households were randomly selected from each category of farmers. This resulted a sample of 120 farmers comprising of 72 marginal, 22 small, 14 medium and 12 large farmers. Tabular analysis was carried out to analyze the data. Averages and percentages were used to facilitate interpretation and comparison of result. In addition, functional analysis was carried out to work out the factors affecting farmer's income.

Multiple log linear regression model was used to work out the affect of various factors, affecting farmers income. The Regression model is:

$$
\begin{aligned}
\ln Y= & a+b 1 \ln X 1+b 2 \ln X 2+b 3 \ln X 3+b 4 \ln X 4 \\
& +b 5 X 5+b 6 X 6+b 7 \ln X 7+e
\end{aligned}
$$

Where $Y$ is the dependent variable and $X 1$ to $X 7$ are explanatory variables.

$a=$ intercept

$b 1-b 7=$ regression coefficients

$e=$ error term

The dependent variable $Y=$ Income of the farmers (₹/farm/year)

The explanatory variables are:

$\mathrm{X} 1$ is the age of respondents, which was taken as number;

$X 2$ indicates educational qualification of the respondents and it was taken as years of educational experience;

$\mathrm{X} 3$ depicts size of land holding in hectares;

$X 4$ is the family size in number; 
$X 5$ is the dummy variable for family type $(0=$ nuclear family, 1 = joint family);

$\mathrm{X} 6$ is also a dummy variable for Extension contact ( $0=$ inactive participation, $1=$ active participation); $X 7$ is the number of income sources taken in numbers.

\section{RESULTS AND DISCUSSIONS:}

\section{Distribution of sample population according to age and sex}

The sample households had a total population of 729 members comprising of 380 males and 349 females. The sex ratio of the sample population was found to be 918 females per thousand males which was lower than the state average of 958 females per thousand males according to 2011 Census (Statistical Handbook of Assam, 2017, Directorate of Economics and Statistics, Government of Assam). Out of total population, 25.38 per cent were in the age group below 15 years, 55.97 per cent were in the age group between 15 to 59 years and 18.66 per cent were in the age group of 60 years and above. Thus, the analysis indicated that the group between 15 to 59 years, which is the most potential labour force in agriculture, formed the largest group in the study area (Table 1).

\section{Distribution of sample population according to educational standard}

The details of educational status of the sample population are depicted in Table 2 . The results indicated that the literacy rate was quite high in comparison to the average for Assam, i.e. 72.19 per cent according to 2011 Census (Statistical Handbook of Assam, 2017, Directorate of Economics and Statistics, Government of Assam). Out of total population of respondent farm families, 85.5 per cent of population were found literate and 14.5 per cent were illiterate. Amongst the literate population, most of them were high school level (36.63 percent). The percentages of population having primary, high school and HS level of education were 25.79, 36.63 and 16.32 percent, respectively. Farm population pursuing up to graduate and above level of education were found to be only 6.72 percent.

\section{Factors affecting farm household income}

There are various factors that affect farm household income, which may be quantitative or qualitative. The factors identified under the study are:

Age of the Farmer: Age of the farmers reflects the experience of the same in the farming practices. Frequent exposure to the fields builds the practical knowledge, which in turn helps in selection of

Table 1: Distribution of sample population according to sex and age across farm size

\begin{tabular}{|c|c|c|c|c|c|c|c|c|c|c|c|c|c|}
\hline \multirow{3}{*}{ Farm size } & \multirow{3}{*}{$\begin{array}{l}\text { No. of } \\
\text { households }\end{array}$} & \multicolumn{9}{|c|}{ Age } & \multirow{2}{*}{\multicolumn{3}{|c|}{ Total population }} \\
\hline & & \multicolumn{3}{|c|}{ Below 15 years } & \multicolumn{3}{|c|}{ 15-59 years } & \multicolumn{3}{|c|}{60 years and above } & & & \\
\hline & & $\mathbf{M}$ & $F$ & $\mathrm{~T}$ & $\mathbf{M}$ & $\mathbf{F}$ & $\mathrm{T}$ & $\mathbf{M}$ & F & $\mathrm{T}$ & $\mathbf{M}$ & $\mathrm{F}$ & $\mathrm{T}$ \\
\hline \multirow[t]{2}{*}{ Marginal } & 72 & 63 & 49 & 112 & 114 & 109 & 223 & 49 & 37 & 86 & 226 & 195 & 421 \\
\hline & & (14.96) & (11.64) & (26.6) & (27.08) & $(25.89)$ & $(52.97)$ & (11.64) & $(8.79)$ & (20.43) & $(53.68)$ & $(46.32)$ & $(100)$ \\
\hline \multirow[t]{2}{*}{ Small } & 22 & 12 & 24 & 36 & 44 & 35 & 79 & 9 & 10 & 19 & 65 & 69 & 134 \\
\hline & & $(8.96)$ & $(17.91)$ & $(26.87)$ & $(32.84)$ & $(26.12)$ & $(58.96)$ & $(6.71)$ & $(7.46)$ & (14.18) & $(48.51)$ & $(51.49)$ & $(100)$ \\
\hline \multirow[t]{2}{*}{ Medium } & 14 & 10 & 8 & 18 & 33 & 21 & 54 & 7 & 10 & 17 & 50 & 39 & 89 \\
\hline & & (11.24) & $(8.99)$ & $(20.22)$ & (37.08) & $(23.59)$ & $(60.67)$ & (7.87) & (11.24) & (19.1) & $(56.18)$ & $(43.82)$ & $(100)$ \\
\hline \multirow[t]{2}{*}{ Large } & 12 & 8 & 11 & 19 & 23 & 29 & 52 & 8 & 6 & 14 & 39 & 46 & 85 \\
\hline & & $(9.41)$ & (12.94) & $(22.35)$ & (27.06) & $(34.12)$ & (61.17) & $(9.41)$ & $(7.06)$ & (16.47) & $(45.88)$ & $(54.12)$ & $(100)$ \\
\hline \multirow[t]{2}{*}{ All farms } & 120 & 93 & 92 & 185 & 214 & 194 & 408 & 73 & 63 & 136 & 380 & 349 & 729 \\
\hline & & $(12.76)$ & (12.62) & $(25.38)$ & (29.36) & (26.61) & (55.97) & $(10.01)$ & $(8.64)$ & (18.66) & (52.13) & (47.87) & $(100)$ \\
\hline
\end{tabular}

(Figures in parentheses indicate the percentage to the total population)

$M=$ Male; $F=$ Female; $T=$ Total 
Table 2: Distribution of sample population according to educational standard

\begin{tabular}{|c|c|c|c|c|c|c|c|c|c|c|c|c|c|c|c|c|}
\hline \multirow{2}{*}{$\begin{array}{l}\text { Farm } \\
\text { size }\end{array}$} & \multirow{2}{*}{$\begin{array}{l}\text { Total } \\
\text { population }\end{array}$} & \multicolumn{3}{|c|}{ Total illiterate } & \multicolumn{3}{|c|}{ Primary } & \multicolumn{3}{|c|}{ High school } & \multicolumn{3}{|c|}{ HS passed } & \multicolumn{3}{|c|}{ Graduate } \\
\hline & & $\mathbf{M}$ & $\mathbf{F}$ & $\mathrm{T}$ & $\mathbf{M}$ & $\mathbf{F}$ & $\mathrm{T}$ & $\mathbf{M}$ & $\mathbf{F}$ & $\mathrm{T}$ & $\mathbf{M}$ & $\mathbf{F}$ & $\mathrm{T}$ & $\mathbf{M}$ & $\mathbf{F}$ & $\mathbf{T}$ \\
\hline \multirow[t]{2}{*}{ Marginal } & 421 & 38 & 31 & 69 & 53 & 67 & 120 & 101 & 77 & 178 & 28 & 11 & 39 & 6 & 9 & 15 \\
\hline & & $(9.03)$ & $(7.36)$ & $(16.3)$ & $(12.5)$ & $(15.9)$ & $(28.5)$ & (23.99) & $(18.29)$ & $(42.28)$ & $(6.65)$ & $(2.61)$ & $(9.26)$ & $(1.43)$ & $(2.14)$ & $(3.56)$ \\
\hline \multirow[t]{2}{*}{ Small } & 134 & 10 & 6 & 16 & 17 & 12 & 29 & 23 & 22 & 45 & 9 & 17 & 26 & 6 & 12 & 18 \\
\hline & & $(7.46)$ & $(4.48)$ & $(11.9)$ & $(12.6)$ & $(8.96)$ & $(21.64)$ & $(17.16)$ & $(16.42)$ & $(33.58)$ & $(6.71)$ & (12.69) & $(19.4)$ & $(4.48)$ & $(8.96)$ & $(13.43)$ \\
\hline \multirow[t]{2}{*}{ Medium } & 89 & 9 & 3 & 12 & 8 & 10 & 18 & 15 & 13 & 28 & 16 & 9 & 25 & 2 & 4 & 6 \\
\hline & & (10.11) & (3.37) & (13.4) & $(8.99)$ & $(11.2)$ & $(20.22)$ & (16.85) & $(14.61)$ & $(31.46)$ & (17.98) & (10.11) & $(28.09)$ & $(2.25)$ & $(4.49)$ & $(6.74)$ \\
\hline \multirow[t]{2}{*}{ Large } & 85 & 5 & 4 & 9 & 12 & 9 & 21 & 7 & 9 & 16 & 13 & 16 & 29 & 2 & 8 & 10 \\
\hline & & (5.89) & $(4.71)$ & (10.5) & (14.1) & (10.5) & $(24.71)$ & $(8.24)$ & (10.59) & $(18.82)$ & (15.29) & $(18.82)$ & $(34.12)$ & (2.35) & (9.41) & $(11.76)$ \\
\hline \multirow{2}{*}{$\begin{array}{l}\text { All } \\
\text { farms }\end{array}$} & 729 & 62 & 44 & 106 & 90 & 98 & 188 & 146 & 121 & 267 & 66 & 53 & 119 & 16 & 33 & 49 \\
\hline & (100) & (8.5) & $(6.04)$ & $(14.5)$ & $(12.3)$ & $(13.4)$ & (25.79) & (20.03) & $(16.59)$ & $(36.63)$ & (9.05) & (7.27) & (16.32) & (2.19) & (4.53) & $(6.72)$ \\
\hline
\end{tabular}

(Figures in parentheses indicate the percentage to the total population)

$M=$ Male $F=$ Female $;=$ Total

proper cultivation practices. But with the invention of new technology, the old age practices become obsolete and sometimes it gets difficult to divert the mind of a particular age group of a farmer from a traditional old age practices to the new improved technology. The reason behind that is extreme poverty of those people, which makes them unable to access it or lack of confidence of the farmer on the new technology. However, the government advances subsidy to make the technologies accessible to the farming community, but age, formal procedures , illiteracy are some factors which throw hindrance in the course of adoption.

Education of the farmer: Education of the farmers is another indisputable factor. Knowledge helps a person in taking better decisions in life. An educated farmer not only focuses on the improved technology for better harvest, but also engages himself in keeping farm records of past experiences and thereby proceeds in a smart way. It also helps in adoption of improved technology.

Cultivated Area: Generally, with per unit increase in the cultivated area or in the unit size of livestock, the production increase, and so does the income. But the increase in production is not analogous with the increase in cultivated area due to diminishing marginal return in case of agricultural production. Operational land holding of a farmer constitutes land under crops, rearing of livestock, poultry and pisciculture. Integrated farming is a great approach, which allows a farmer to increase or utilize the space horizontally or vertically.

Family type/ family size: Family type and family size also affect the farm household income. With increase in the number of family member, the consumption expenditure increases, as a result of which the marketable surplus declines and hence the ultimate profit from the production. However, this scenario may be different for the households with off-farm income earnings.

Extension contact and social participation: Extension contact and social participation acquaints the farmers with the new emerging techniques of cultivation practices and also helps them to be in active contact with the extension agencies. Moreover, it helps in developing leadership quality; thereby one farmer can spread the knowledge easily to the other farmers in his locality. Social participation makes a person to be able to hold the confidence of the fellow farmer upon him, which is a very crucial factor to be considered prior to disseminating any technology.

Number of income sources: Number of income sources is the final factor that is being considered under study. Increase in the number of income sources enhances the gross income of the farm households. Households may be involved in different income generation activities other than agricultural activities, such as business, daily wage earning and salaried jobs. Such kind of income 
earned from above mentioned activities, which are distinguished from the on farm activities are often termed as off-farm income. On-farm income source constitutes crop cultivation, livestock production, poultry production, pisciculture.

\section{Effect of identified factors on farm income}

The estimates of the effect of factors on farm household income are presented in the Table 3.

Table 3: Factors affecting farm household income

\begin{tabular}{lll}
\hline Independent variables & Coefficients & $\begin{array}{l}\text { Standard } \\
\text { error }\end{array}$ \\
\hline Intercept & 2.21 & 0.28 \\
Age & 0.84 & 0.18 \\
Education & $0.61^{* * *}$ & 0.19 \\
Size of land holding & $0.17^{*}$ & 0.05 \\
Family size & 0.22 & 0.13 \\
Family type & 0.03 & 0.03 \\
Extension contact & $0.09^{* * *}$ & 0.04 \\
Number of income sources & $0.44^{* *}$ & 0.16 \\
\hline
\end{tabular}

$\left({ }^{*} 1 \%\right.$ significant, ${ }^{* *} 5 \%$ significant, ${ }^{* * *} 10 \%$ significant) Adjusted $R^{2}$ : 0.86; Standard error: 0.11; Observation : 120

From the table, it is observed that there was a positive relationship of household income of the farmers with every factor considered in the study. The regression coefficient of 'size of land holding' was estimated to be 0.17 , which indicates that keeping other factors constant, one percent increase in size of land holding would increase income of the farm household by 0.17 percent. Four variables were found to be significant from the study, which were education, size of land holding, extension contact and numbers of income sources with regression coefficients $0.61,0.17,0.09,0.44$, respectively. It implies that income of the farm household can be increased through enhancing the educational level, increasing the size of land holding, more extension contact and raising the number of income sources. The regression coefficients of age, family type and family size were found to be positive, but not significant.

The coefficient of multiple determination $\left(\mathrm{R}^{2}\right)$ was found to be 0.86 , which implies that the independent variables (different factors considered) are 86 percent responsible for the changes in the dependent variable (income of the farm household).
Parvin and Akteruzzaman (2013) found that family size and farm size had a significant positive effect on farm income. But the non farm income had a significant negative effect on farm income. Age of the respondents was also found to be positively related with the income of the respondents, but not significant. The literacy level showed a negative effect on farm income.

\section{CONCLUSIONS}

The study revealed that, in the study area individuals in the age group of 15-59 years, which is considered as the potential labour force, accounted for 55.97 per cent of total population. The sex ratio in the sample population was 918 females per 1000 males, which was lower than the state average. It was also reported that most of the sample respondents had higher secondary level of education and few of them had graduation degree. Total literate population was estimated to be 85.5 percent.

The major factors which affect the farm income in the study area were education of the farmer, size of land holding, extension contact, numbers of income sources, age of the farmer and family type or family size. Out of the seven factors considered in regression analysis, four factors were found to be the significant. Those four factors are education, size of land holding, extension contact and number of income sources. There was a positive relationship of income of the household farmers with every seven factors considered. However, the effects of age of the farmer and family type were not significant. The goodness of fit was estimated to be 0.86 .

\section{Policy measures}

Education, size of land holding, extension contact and number of income sources were found to be the significant and holding positive relationship with the farm household income. Intellectual minds always perform any task in a smart way and when it comes to farming, a calculative mind is crucial for better allocation of resources. Government should make agriculture, a compulsory subject in the school level. It's very essential to make the people of a country realize about the significance of agriculture. Incorporation of agriculture as a subject will not only help people to acquaint themselves with the scientific farming activities at an early stage of their life, but also motivate them towards farming. 
Increase in income is preceded by increase in production, but it's not possible with small land holdings. Farmers should be taught about the importance of co-operative farming and subsidy should be provided, which will capture the mind of the farmers. Such type of farming allows the farmers to grow at a large scale and improve the risk bearing capacity of the farming system.

Strengthening the extension agencies is another measure for augmenting farm household income. Apart from organizing training programs on cultivation practices, those agencies should also focus on imparting knowledge regarding marketing of the farm produce.

More the number of income sources, the more will be the gross income. So, the people should follow multiple cropping and integrated farming is the best option. However, farmers can form some self help groups amongst them and start doing some off-farm activities, which will also increase the income sources.

\section{REFERENCES}

Bhaumik, S.K. 2007. Diversification of Employment and Earnings by Rural Households in West Bengal. Indian Journal of Agricultural Economics, 62: 585-605.

Bhaumik, S.K. 2007. Occupational Diversification among Rural Workers: Results from Field Surveys in West Bengal. Indian Journal of Agricultural Economics, 50: 673-688.

Hassan, Thabit. 2015. Economic Analysis of Factors Affecting the Farmer Income under Traditional Farming System in South Darfur State- Sudan. Journal of Agricultural Science and Engineering, 3: 114-119.
Mabe, L.K., Antwi, M.A. and Oladele, O.I. 2010. Factors Influencing Farm Income in Livestock Producing Communities of North-West Province, South Africa. Livestock Research for Rural Development, 22(8): 2010.

McNamara, K.T. and Weiss, C. 2005. Farm Household Income and On-and Off-Farm Diversification. Journal of Agricultural and Applied Economics, 37: 37-48.

Parvin, M.T. and Akteruzzaman, M. 2012. Factors Affecting Farm and Non-Farm Income of Haor Inhabitants of Bangladesh. Progressive Agriculture, 23: 143-150.

Ranganathan, T. 2015. Farmers' income in India: evidence from secondary data. A study submitted to Ministry of Agriculture. New Delhi: Institute of Economic Growth, New Delhi, India. Available from URL: http://www. iegindia.org/ardl/Farmer_Incomes_Thiagu_Ranganathan. pdf. [Accessed June 15, 2018].

Safa, M.S. 2008. Socio Economic Factors Affecting The Income of Small Scale Agro-Forestry Farms in Hill Country Areas in Yemen: A Comparison of OLS and WLS Determinants. Small-scale Forestry, 4: 117-134.

Saha, B. and Bahal, R. 2014. Livelihood Diversification Pattern among the Farmers of West Bengal. Economic Affairs, 59: 321-334.

Saikia, K.N. and Goswami, C. 2015. Nature and Extent of Income Diversification: A Study of Rural Households in Assam. International Journal of Economics, Commerce and Research, 5: 43-54.

Sharma, Y.K., Bangarva, G.S. and Sharma, S.K. 2007. Factors Affecting Gross and Net Income of Farmers in Different Farming Systems. Indian Research Journal of Extension Education, 7: 52-56. 